\title{
EDUKASI GIZI YANG SEHAT UNTUK PENCEGAHAN STUNTING DI KELURAHAN BENDA BARU KECAMATAN PAMULANG TANGERANG SELATAN
}

\author{
Rusilanti ${ }^{1, a)}$, Nur Riska ${ }^{1, b)}$ \\ Universitas Negeri Jakarta, \\ Jl. Rawamangun Muka, RT.11/RW.14, Rawamangun, Pulo Gadung, Kota \\ Jakarta Timur, Daerah Khusus Ibukota Jakarta 13220 \\ Email : ${ }^{\text {a) }}$ usilanti@unj.ac.id, ${ }^{\text {b) }}$ nrtadjoedin@unj.ac.id
}

\begin{abstract}
The number of malnutrition in Indonesia is considered high with the results of the Nutrition Status Monitoring conducted by the Indonesian Ministry od Health in 2016, the nutritional status of children aged $0-59$ months shows the percentage of malnutrition is $3.4 \%$ and under nourished is $14.4 \%$ (depkes.go.id, 2018). One of the effects of malnutrition is the occurrence of grow short in children or often referred to as stunting. In $201722.2 \%$ or around 150.8 million toddlers in the world were stunted. The aim of the implementation of the community service program was to develop the welfare section, namely the productivity of the culinary business a manufacture of processed mackerel and soybean through nutrition education to prevent stunting and increase the family economy. The methodology used in this community service program are planning and training productive community partnership programs. The mechanisms for implementing this activity are present material content, and indirect practice. Community service activities that have been carried out in Benda Baru, Pamulang, South Tangerang has been conducted online. The results obtained from the community service program based on of knowledge aspect, there was an increase with a difference of 32.2 obtained from the result of the pre-test and post-test and having skills on several examples of processed food products made from mackerel and soybean which contain high protein to prevent stunting.
\end{abstract}

Keywords: Education; Stunting; Mackerel; Soybeans

\begin{abstract}
Abstrak
Angka gizi buruk di Indonesia terhitung tinggi menurut hasil Pemantauan Status Gizi (PSG) yang dilakukan Kementerian Kesehatan tahun 2016, status gizi balita usia 0-59 bulan menunjukkan persentase gizi buruk sebesar 3,4\% dan gizi kurang sebesar 14,4\% (depkes.go.id, 2018). Salah satu dampak dari kekurangan gizi adalah terjadinya tumbuh pendek pada anak atau sering disebut dengan stunting. Tahun 2017, 22,2\% atau 150,8 juta balita di dunia mengalami stunting. Tujuan dari pelaksanaan program PPM (Pengabdian Pada Masyarakat) ini adalah mengembangkan bidang kesejahteraan yakni produktivitas usaha kuliner berbahan dasar ikan kembung dan kacang kedelai melalui edukasi gizi pencegahan stunting serta dapat menambah perekonomian keluarga. Metodologi yang digunakan pada program PPM ini adalah perencanaan dan pelatihan program kemitraan masyarakat produktif. Mekanisme pelaksanaan kegiatan ini adalah pemberian materi, dan praktek online. Kegiatan PPM yang telah dilaksanakan di Kelurahan Benda Baru, Pamulang, Tangerang Selatan ini telah dilakukan secara online. Hasil yang diperoleh dari program PPM berdasarkan aspek pengetahuan, terjadinya peningkatan dengan selisih 32,2 yang diperoleh dari hasil pre test dan post test serta mempunyai keterampilan tentang beberapa contoh produk olahan makanan berbahan dasar ikan kembung dan kacang kedelai yang mengandung protein tinggi untuk mencegah stunting.
\end{abstract}

Kata Kunci: Edukasi; Stunting; Ikan kembung; Kacang kedelai 


\section{PENDAHULUAN}

Angka gizi buruk di Indonesia terhitung tinggi dengan hasil Pemantauan Status Gizi (PSG) yang dilakukan Kementerian Kesehatan pada tahun 2016, status gizi pada balita usia 059 bulan menunjukkan persentase gizi buruk sebesar 3,4\% dan gizi kurang sebesar 14,4\% (Kemenkes RI, 2018). Salah satu dampak dari kekurangan gizi adalah terjadinya tumbuh pendek pada anak atau sering disebut dengan stunting. Kejadian balita pendek atau biasa disebut dengan stunting merupakan salah satu masalah gizi yang dialami oleh balita di dunia saat ini. Pada tahun 2015 balita stunting mencapai angka 29\% (Kemenkes RI, 2016). Upaya perbaikan gizi masyarakat ditujukan untuk peningkatan mutu gizi perseorangan dan masyarakat, melalui antara lain a) perbaikan pola konsumsi makanan, dan b) peningkatan akses dan mutu pelayanan gizi.

Stunting adalah suatu keadaan di mana tinggi badan seseorang diketahui lebih pendek jika dibandingkan dengan tinggi badan orang lain yang sebaya dengannya. Prevalensi stunting bayi berusia di bawah lima tahun (balita) Indonesia pada 2015 sebesar 36,4\%. Artinya lebih dari sepertiga atau sekitar 8,8 juta balita mengalami masalah gizi di mana tinggi badannya di bawah standar sesuai usianya. Stunting tersebut berada di atas ambang yang ditetapkan WHO sebesar 20\%. Prevalensi stunting/kerdil balita Indonesia ini terbesar kedua di kawasan Asia Tenggara di bawah Laos yang mencapai 43,8\% (UNICEF, 2017).
Angka stunting di Indonesia termasuk tinggi bergaris lurus dengan angka gizi buruk. Penyebab utama dari terjadinya kasus stunting adalah kurangnya asupan gizi yang diterima sejak 1000 hari pertama kehidupan. Kurangnya kesadaran dan pengetahuan ibu tentang pentingnya asupan gizi dan pola pengasuhan yang baik untuk anak juga turut menjadi penyebab timbulnya stunting. Selain itu, terbatasnya akses masyarakat terhadap makanan bergizi, air bersih, sanitasi, dan fasilitas kesehatan menjadi penyebab lain terjadinya stunting (Tentama et al., 2018).

Makanan ibu sewaktu hamil hendaknya mengandung jumlah dan mutu gizi yang baik. Bila ibu hamil makan makanan yang rendah baik jumlah maupun mutu gizinya, dapat menyebabkan kemunduran kesehatan janin. Pada ibu hamil kebutuhan omega 3 dan protein meningkat hal ini harus didukung oleh pola konsumsi yang baik. Beberapa cara yang dapat dilakukan adalah meningkatkan konsumsi ikan.

Beberapa hasil yang telah dilakukan sebagai upaya pencegahan stunting antara lain menunjukkan upayaupaya yang telah dilakukan pemerintah untuk mengatasi stunting selama ini diantaranya adalah Pemberian Makanan Tambahan (PMT) pada Balita dan Ibu Hamil, Pemberian Tablet Tambah Darah (TTD) pada remaja putri dan ibu hamiL, peningkatan cakupan imunisasi dasar lengkap pada bayi dan balita, pemberian vitamin A pada balita, dan pemberian zinc pada kasus diare terutama pada ibu hamil dan balita (Saputri, 2019). 
Hasil menunjukkan bahwa terdapat 5 faktor yang berpengaruh terhadap keberhasilan program pemberdayaan masyarakat yaitu (1) perencanaan dan sosialisasi (2) pendampingan dan pemberian motivasi kepada kelompok sasaran, (3) pelatihan pemanfaatan hasil pekarangan mendukung diversifikasi konsumsi pangan, (4) monitoring dan evaluasi pelaksanaan program dan dampaknya, (5) pentingnya aspek promosi dan pemasaran. Jika pemberdayaan masyarakat optimal pada programprogram ini maka pencegahan stunting di era new normal ini akan mendapatkan hasil yang optimal (Candarmaweni \& Yayuk Sri Rahayu, 2020).

Demikian juga hasil kajian menunjukkan Kebijakan penanggulangan stunting terkesan masih berada pada tataran menara gading, sementara pada tataran akar rumput sendiri yang merupakan ujung tombak upaya percepatan penanggulangan stunting, isu stunting seolah masih terdengar asing. Oleh karena itu, masih sangat diperlukan sosialisasi secara massif terkait stunting, dampak yang ditimbulkan, urgensi penanggulangannya, dan upaya penanggulangan stuntingpada tataran akar rumput, sebagai bentuk upaya preventif individual tanpa bergantung pada program pemerintah saja, sebab penanggulangan stunting adalah masalah mendesak yang mesti ditangani oleh semua pihak dengan segera tanpa menunggu apapun (Tumangger, 2019).

Sementara hasil kajian lainnya menunjukkan peningkatan pengetahuan bagi ibu hamil dan pemberian pola asuh yang baik kepada bayi dan balita memiliki andil dalam penanggulangan stunting. Oleh karena itu, pemerintah perlu mendorong semua stakeholder untuk ikut berperan menyelamatkan anak balita dari stunting. Ketersediaan pendampingan secara intensif dan berkesinambungan, serta keterlibatan semua kementerian/lembaga merupakan sarana untuk mengakselerasi pengurangan kasus stunting di Indonesia. DPR RI, terutama Komisi IX perlu melakukan pengawasan lebih intensif dan menyeluruh terhadap kesehatan khususnya kesehatan anak dan ibu hamil yang mengalami gizi buruk, serta mendorong Kementerian Kesehatan melakukan pendampingan secara khusus guna menekan angka stunting di Indonesia (Teja, 2019).

Kecamatan Pamulang merupakan salah satu Kecamatan yang ada di Kota Tangerang Selatan, dimana wilayahnya terbagi menjadi 8 desa. Namun seiring dengan laju perkembangan zaman yang diimbangi dengan pesatnya pertumbuhan penduduk dan ekonomi, sebagai daerah penyangga ibu kota Negara, Desa Benda Baru akhirnya berubah Status dari Desa menjadi Kelurahan yaitu pada tanggal 19 September 2005 bersama dengan 76 Desa Lainnya di Kabupaten Tangerang pada waktu itu berdasarkan peraturan Daerah Kabupaten Tangerang Nomor 3 tahun 2005. Batas Wilayah (Berdasarkan Perda Kab. Tangerang No 3 Tahun 2005): Sebelah Utara berbatasan dengan : Kelurahan Serua (Kecamatan Ciputat), Sebelah Selatan berbatasan 
dengan: Kelurahan Pondok Benda, Sebelah Barat berbatasan dengan: Kelurahan Pondok Benda, dan Sebelah Timur berbatasan dengan: Kelurahan Pamulang Barat.

Pemanfaatan potensi lokal di daerah Kecamatan Pamulang ini merupakan salah satu inovasi yang tepat guna. Kementrian Perikanan sedang mencanangkan Forum Peningkatan Konsumsi Ikan (FORIKAN), hal ini terkait dengan sumber perairan yang melimpah dan gencarnya pemerintah dalam mensosialisasikan kepada masyarakat tentang pentingnya konsumsi ikan. Sehingga meningkatkan kesadaran masyarakat untuk merubah pola makan yang semula bersumber dari hasil peternakan, beralih pada hasil perikanan. Hal ini dimanfaatkan oleh sebagian masyarakat untuk melakukan berbagai macam diservifikasi terhadap produk perikanan.

Departemen perikanan dan kelautan produksi total perikanan tahun 2017 mencapai kurang lebih 23,51 juta ton. Hasil survei sosial ekonomi nasional (2017) konsumsi ikan mencapai kurang lebih 46,49 per $\mathrm{kg} / \mathrm{kap} / \mathrm{tahun}$. Bersadarkan profil kelautan dan perikanan produksi ikan kembung mencapai 9.928,8 ton pada tahun 2016 dilaut jawa. Menurut KKP (2017) tangkapan ikan kembung setiap tahun ditingkatkan. Ikan kembung memiliki beberapa kelebihan yang tangkapannya melimpah, harga relatif murah, mudah didapat serta memiliki kandungan asam lemak tidak jenuh ensesial yang penting untuk tubuh. Ikan kembung mempunyai kandungan omega 3 dan protein yang tinggi yang berguna untuk perbaikan gizi masyarakat (Damayanti; D.S. Jastam, M.S; dan Faried, 2017).

Selain meningkatkan jumlah konsumsi ikan ibu hamil pun dapat mengkonsumsi kacang-kacangan. Sekitar 90 kedelai tersedia di Indonesia, digunakan sebagai bahan pangan dan sianya untuk pakan ternak dan benih (FAOSTAT, 2005). Konsumsi kedelai terus meningkat seiring dengan bertambahnya jumlah penduduk, sehingga sebagian besar harus di impor karena produksi dalam negeri belum memenuhi kebutuhan. Dengan tingkat konsumsi $8,10 \mathrm{~kg} / \mathrm{kapita} / \mathrm{tahun}$ pada tahun 2005. Kacang kedelai mengandung protein $37,58 \mathrm{mg} / 100 \mathrm{~g}$. Dengan demikian dalam upaya pemberdayaan masyarakat sebagai upaya pencegahan stunting dapat dilakukan dengan memberikan pendidikan pada masyarakat dengan memanfaatkan ikan dan kedelai sebagai bahan dasar pembuatan makanan bagi remaja putri, ibu hamil, dan ibu menyusui.

\section{TINJAUAN LITERATUR}

Indonesia menempati ranking ke 5 dari 81 negara dengan jumlah anak stunting terbanyak di dunia. Pada tahun 2015 di Indonesia terdapat 18,9\% anak pendek, dan $10,1 \%$ anak sangat pendek. Di tahun 2016 jumlah anak pendek di Indonesia 19\% dan anak sangat pendek $8,6 \%$. Hal itu terjadi pada anak usia 0-59 bulan (Hardhana et al., 2017). Pada tahun 2018 jumlah anak stunting di Indonesia sebanyak 30,8\% (Kementrian Kesehatan RI, 2018). 
Ketahanan pangan rumah tangga berkaitan dengan harga makanan. Tingginya harga makanan, menyebabkan masyarakat membeli makanan yang murah dan tidak bergizi sehingga memberikan peluang terjadinya stunting, defisiensi zat gizi mikro, dan rendahnya kesehatan bayi yang dilahirkan (Meerman \& Aphane, 2012). Hal itu sejalan dengan kajian yang dilakukan di Indonesia menunjukkan semakin tingginya harga makanan, semakin rendah intake makanan bergizi pada masyarakat yang memberikan peluang terjadinya stunting (Mahmudiono, Trias and Sumarmi, Sri and Rosenkranz, 2017).

Untuk mencegah terjadinya stunting di Indonesia dalam kondisi tingginya harga makanan yang menyebabkan kurang berkualitasnya konsumsi makanan pada masyarakat yang berpenghasilan rendah, diperlukan adanya edukasi ke masyarakat tentang stunting dan bahan makanan yang bergizi dan harga terjangkau dengan cara pengolahan makanan yang disukai masyarakat. Hal ini didukung oleh penelitian yang menunjukkan pentingnya dilakukan desain program Kesehatan masyarakat untuk mencegah stunting dan efek stunting jangka Panjang untuk meningkatkan Kesehatan dan kesejahteraan masyarakat (Hall et al., 2018).

Program pengabdian masyarakat ini mencakup pengembangan kemampuan kognitif dan keterampilan. Program pengembangan dilakukan melalui serangkaian proses pemberian rangsangan pendidikan oleh pendidik, respon masyarakat, intervensi pendidik, dan penguatan oleh pendidik. Penggalian informasi permasalahan dan potensi wilayah dilakukan melalui kegiatan Pemetaan wilayah. Kegiatan pemetaan wilayah, melibatkan partisipasi kaum perempuan sehingga hasil pemetaan terkait dengan desa produktif terhadap produk lokal yang mempunyai keunikan dan potensi untuk diperdayakan sebagai kawasan kelurahan Benda Baru, Kecamatan Pamulang, Tangerang Selatan memiliki berbagai kebutuhan yang mencakup berbagai aspek baik fisik maupun non fisik.

Secara garis besar pelaksanaan program ini adalah pemberdayaan masyarakat dalam penyusunan Rencana Program Pengabdian Masyarakat bagi masyarakat di Kelurahan Benda Baru, Kecamatan Pamulang, Tangerang Selatan dalam bentuk diversifikasi produk makanan yang disusun dengan maksud untuk memberikan pemahaman kepada ibu hamil tentang pentingnya makanan bergizi tinggi dan mengandung protein serta asam folat untuk mencegah stunting dan dalam rangka mendukung program pemerintah untuk menurunkan angka stunting di Indonesia untuk menghasilkan generasi penerus bangsa yang berkualitas serta meningkatkan kualitas sumber daya manusia.

Berdasarkan analisis situasi di atas, maka diadakan program pengabdian masyarakat ini mencakup pengembangan kemampuan kognitif dan keterampilan untuk menciptakan suatu kondisi yang lebih baik dalam satu waktu tertentu (sustainable) sehingga 
terwujudnya wilayah potensial melalui pengoptimalan ikan dan kacangkacangan menjadi produk aneka olahan ikan dan kacang-kacangan yang berkualitas dan bergizi sebagai salah satu upaya pencegahan stunting. Diharapkan dengan bertambahnya pengetahuan orang tua tentang stunting dan bagaimana cara mengolah ikan dan kacang-kacangan yang disukai ibu hamil, ibu menyusui dapat meningkatkan status gizi dan menghindari terjadinya stunting.

\section{METODE PELAKSANAAN}

Pada pelaksanaan program PPM ini, dilakukan dengan mitra Kelurahan Benda Baru, Kecamatan Pamulang, Kota Tangerang Selatan yang merupakan masyarakat produktif yang melaksanakan setiap program-program pemerintah kota. Adapun perencanaan dan desain kemitraan desa ini melalui langkah-langkah sebagai berikut. Beberapa hal yang perlu diperhatikan untuk mengikut sertakan masyarakat dalam penyusunan desa terampil dan mandiri adalah:

1) Kesepakatan dan kesepahaman dalam penerapan perencanaan

2) Penyesuaian perencanaan berdasarkan aspirasi dari masyarakat

3) Penerapan prioritas perencanaan dan pelaksanaan melalui Whatsapp group, video dan Youtube.

4) Transparansi dengan melakukan monitoring dan evaluasi secara terbuka.
Langkah-langkah

untuk mewujudkan perencanaan dan pelatihan program kemitraan masyarakat adalah:

a. Pendekatan kepada pemuka masyarakat setempat dan izin dari pemimpin wilayah (dusun, RW/RT), dan mitra

b. Pendekatan kepada warga yang mempunyai kemauan, kepedulian dan kemampuan untuk melaksanakan program serta dapat menjadi penggerak di lingkungannya.

c. Pemetaan masalah-masalah lingkungan setempat dari berbagai aspek.

d. Mengidentifikasi bahan dan alat yang dapat digunakan dalam pembuatan olahan makanan dari ikan kembung dan kacang kedelai bagi masyarakat di Kelurahan Benda Baru, Kecamatan Pamulang, Kota Tangerang.

e. Mengundang masyarakat di Kelurahan Benda Baru, Kecamatan Pamulang, Kota Tangerang untuk hadir dalam kegiatan PKM.

f. Melakukan penyuluhan gizi tentang kasus stunting, wnita dewasa dan ibu hamil.

g. Melakukan pelatihan pembuatan olahan makanan dari ikan kembung dan kacang kedelai seperti fish stick, tahu ikan mahkota, puding soya mutiara, bolu kukus soya.

h. Evaluasi program melalui kegiatan pre test dan post-test pengetahuan serta keterampilan masyarakat dalam pembuatan olahan makanan 


$\begin{array}{llr} & \text { di Kelurahan Benda Baru, } \\ \text { Kecamatan Pamulang, } & \text { Kota } \\ \text { Tangerang melalui kegiatan } \\ \text { pengolahan. }\end{array}$
berbasis bahan pangan lokal sangat penting untuk dikembangkan, karena dapat meningkatkan ekonomi keluarga. Sehingga perlu adanya pendekatan kepada masyarakat yang berada di daerah Kelurahan Benda Baru, Kecamatan Pamulang, Kota Tangerang Selatan untuk menghasilkan beberapa jenis bahan pangan lokal sebagai bahan makanan bergizi yang mempunyai prospek untuk dikembangkan menuju ketahanan pangan yang berkelanjutan. Bagi masyarakat Indonesia secara umum, pengetahuan mengenai berbagai pilihan bahan pangan yang tetap bergizi dan berbasis lokal akan lebih bermanfaat dalam mendorong konsumsi masyarakat Indonesia ke bahan pangan lokal.

Program pengabdian kepada masyarakat ini ditujukan kepada masyarakat sebanyak 20-30 orang. Program pengabdian kepada masyarakat ini diharapkan mampu membantu memberdayakan ekonomi keluarga melalui peran para ibu rumah tangga di dusun tersebut dengan memanfaatkan bahan baku pangan lokal. Dalam jangka panjang usaha pemanfaatan bahan pangan lokal yang ada bisa memunculkan unit usaha di daerah tersebut yang dapat membantu meningkatkan kesejahteraan warga setempat.

Mekanisme pelaksanaan kegiatan ini adalah pemberian materi, praktek secara langsung, dan pendampingan. Pemberian materi dilakukan di aula setempat, dengan memberikan materi tentang inovasi pangan bahan lokal untuk mengenalkan berbagai pilihan alternatif sumber pangan dan mengenalkan beberapa contoh inovasi pangan berbasis bahan lokal yang ada. Teknik pembuatan produk olahan inovasi dengan bahan dasar ikan kembung dan kacang kedelai dan pendampingan serta praktek pembuatan aneka olahan makanan di wilayah Kelurahan Benda Baru, Kecamatan Pamulang, Kota Tangerang Selatan. Adapun secara lebih rinci, tahapan dan metode dalam pelaksanaan kegiatannya :

1. Ceramah digunakan untuk penyampaian pengetahuan edukasi gizi secara umum tentang kasus stunting, wanita dewasa dan ibu hamil, upaya pencegahan stunting serta asupan makanan bergizi.

2. Ceramah tentang pangan lokal, yang meliputi jenis, nilai gizi, manfaat dan teknik pengolahan ikan kembung dan kacang kedelai.

3. Demonstrasi digunakan untuk memberikan keterampilan secara langsung mengenai proses pengolahan pangan lokal, peralatan yang diperlukan serta bahan tambahan makanan yang digunakan dalam pengolahan. Tanya jawab digunakan untuk melengkapi hal-hal yang belum 
terakomodasi oleh kedua metode di atas.

4. Pelatihan pengembangan produk olahan inovasi ikan kembung dan kacang kedelai menjadi berbagai produk olahan yang ditujukan kepada masyarakat Kelurahan Benda Baru, Kecamatan Pamulang, Kota Tangerang Selatan.

5. Evaluasi hasil pelatihan dilakukan selama proses dan setelah kegiatan pelatihan dilaksanakan.

6. Pengukuran kepuasan peserta terhadap pelaksanaan pengabdian masyarakat.

\section{HASIL DAN PEMBAHASAN}

Kegiatan pengabdian pada masyarakat yang telah dilaksanakan di Kelurahan Benda Baru, Kecamatan Pamulang, Kota Tangerang Selatan ini telah dilakukan secara online, dengan alasan bahwa saat ini bangsa Indonesia dan seluruh dunia mengalami masa pandemic COVID-19 yang mana tidak diperbolehkannya adanya kegiatan yang mengumpulkan orang banyak.

Pelatihan pengabdian pada masyarakat ini yang dilakukan secara online dengan bantuan media video (youtube), dilaksanakan oleh para Dosen yang mempunyai kompetensi di bidangnya, seperti Ibu Dr. Rusilanti, M.Si sebagai narasumber dalam memberikan pengetahuan gizi tentang stunting dan Ibu Nur Riska, S.Pd, M.Si sebagai narasumber dalam memberikan keterampilan olahan makanan sehat berbahan dasar ikan kembung dan kacang kedelai, dimana kedua bahan tersebut merupakan contoh bahan yang mengandung protein yang tinggi.

Dalam kegiatan ini, narasumber melibatkan mahasiswa sebanyak 5 orang guna membantu proses persiapan, pelaksanaan dan pelaporan. Keterlibatan mahasiswa diharapkan dapat memberikan pengalaman langsung dalam menghadapi masyarakat yang memang benar-benar membutuhkan pengetahuan dan keterampilan dari dunia akademisi.

Kegiatan pengabdian kepada masyarakat ini diikuti oleh ibu-ibu rumah tangga, ibu hamil dan wanita dewasa yang sedang merencanakan program kehamilan di Kelurahan Benda Baru, Kecamatan Pamulang, Kota Tangerang Selatan. Total peserta yang mengikuti pelatihan pemanfaatan ikan kembung dan kacang kedelai menjadi produk makanan guna mencegah stunting melalui edukasi gizi dan pembuatan aneka olahan sebanyak 14 orang peserta. Usia peserta berkisar antara usia $30 \mathrm{~s} / \mathrm{d} 55$ tahun.

Pelatihan pemanfaatan ikan kembung dan kacang kedelai menjadi produk makanan guna mencegah stunting diberikan kepada ibu-ibu rumah tangga, ibu hamil dan wanita dewasa yang dilakukan secara online melalui video youtube dan whatsapp group. Pelatihan ini dilakukan dalam rangka meningkatkan pengetahuan tentang stunting, upaya dan asupan makanan yang bergizi untuk mencegah stunting dan keterampilan tentang olahan produk makanan sehat berbahan dasar ikan kembung dan kacang kedelai yang dilaksanakan secara online melalui 
media video youtube selama 2 hari yaitu pada hari pertama yaitu hari Minggu, 23 Agustus 2020 pukul $09.00 \mathrm{~s} / \mathrm{d} 16.00$ WIB, dah hari kedua yaitu hari Senin, 24
Agustus 2020 pukul 09.00 s/d 16.00 WIB. Adapun rincian pelaksanaan kegiatan adalah sebagai berikut :

Tabel 1. Rincian Kegiatan Pelaksanaan PKM di Kelurahan Benda Baru-Kecamatan Pamulang-Kota Tangerang Selatan

\begin{tabular}{|c|c|c|}
\hline NO & KEGIATAN & KETERANGAN \\
\hline 1 & $\begin{array}{l}\text { Fasilitator memberikan link google form untuk } \\
\text { dapat mengisi absen kehadiran }\end{array}$ & Link Google Form Absensi \\
\hline 2 & $\begin{array}{l}\text { Fasilitator memberikan link google form untuk } \\
\text { dapat mengisi soal pre test terkait dengan materi } \\
\text { stunting dan makanan sehat dari ikan kembung dan } \\
\text { kacang kedelai }\end{array}$ & Link Google Form Pre Test \\
\hline 3 & $\begin{array}{l}\text { Fasilitator melakukan penyampaian informasi } \\
\text { terkait edukasi gizi tentang stunting, upaya dan } \\
\text { asupan makanan guna mencegah stunting melalui } \\
\text { media video youtube }\end{array}$ & $\begin{array}{l}\text { Ceramah melalui video } \\
\text { Tanya jawab melalui } \\
\text { whatsapp group }\end{array}$ \\
\hline 4 & $\begin{array}{l}\text { Fasilitator memberikan keterampilan secara online } \\
\text { melalui media video youtube mengenai proses } \\
\text { pengolahan pangan lokal berbahan dasar ikan } \\
\text { kembung dan kacang kedelai guna mencegah } \\
\text { stunting }\end{array}$ & $\begin{array}{l}\text { Demontrasi dan ceramah } \\
\text { melalui video youtube } \\
\text { Tanya jawab melalui } \\
\text { whatsapp group }\end{array}$ \\
\hline 5 & $\begin{array}{l}\text { Fasilitator mempersilahkan peserta secara mandiri } \\
\text { praktek di rumah untuk pengolahan makanan } \\
\text { berbahan dasar ikan kembung dan kacang kedelai }\end{array}$ & Praktek secara mandiri \\
\hline 6 & $\begin{array}{l}\text { Fasilitator memberikan soal post test terkait materi } \\
\text { yang telah diberikan }\end{array}$ & Link Google Form Post Test \\
\hline 7 & $\begin{array}{l}\text { Fasilitator memberikan lembar umpan balik } \\
\text { peserta terkait dengan materi pelatihan yang } \\
\text { diberikan secara keseluruhan. }\end{array}$ & $\begin{array}{l}\text { Link Google Form Angket } \\
\text { kepuasan peserta }\end{array}$ \\
\hline
\end{tabular}

Kegiatan pertama yang dilakukan adalah dimana fasilitator menyampaikan materi tentang tentang stunting, upaya dan asupan makanan guna mencegah stunting dari segi pengetahuan dan dari aspek keterampilan melalui demonstrasi melalui link video youtube. Hal tersebut diperoleh dari hasil output pelatihan antara lain :

\section{Output (Hasil) Pelatihan}

Output atau luaran yang dihasilkan dari kegiatan ini diantaranya :

a. Ibu rumah tangga, wanita dewasa dan ibu hamil di wilayah Kelurahan Benda Baru, 
Kecamatan Pamulang, Kota Tangerang Selatan mempunyai pengetahuan tentang kasus stunting di Indonesia, upaya pencegahan stunting dan asupan makanan yang baik untuk mencegah stunting.

b. Ibu rumah tangga, wanita dewasa dan ibu hamil di wilayah Kelurahan Benda Baru, Kecamatan Pamulang, Kota Tangerang Selatan mempunyai keterampilan tentang beberapa contoh produk olahan makanan berbahan dasar ikan kembung dan kacang kedelai yang mengandung protein tinggi untuk mencegah stunting.

\section{Efektivitas Pelatihan untuk Aspek Pengetahuan}

Berdasarkan hasil pelatihan yang dikuti oleh 14 orang peserta, mengenai penjelasan tentang materi edukasi gizi tentang stunting, maka dari hasil tanya jawab pengetahuan dan keterampilan membuat dan menyajikan aneka olahan makanan berbahan dasar ikan kembung dan kacang kedelai diperoleh hasil sebagai berikut :

\section{A. Hasil Evaluasi Pre Test}

Hasil pre test menunjukkan bahwa sebanyak 2 peserta (14\%) mendapat nilai 50 ; untuk 7 peserta $(50 \%)$ mendapat nilai 60 ; dan untuk 5 peserta (36\%) mendapatkan nilai 70. Adapun rata-rata nilai hasil pre test sebesar 62,1.

Berdasarkan hasil perhitungan pre test dengan rata-rata sebesar 62,1 menunjukkan bahwa peserta kurang memiliki pengetahuan tentang materi gizi khususnya pentingnya stunting dan bahan makanan seperti ikan kembung dan kacang kedelai yang mempunyai protein yang tinggi untuk mencegah stunting.

\section{B. Hasil Post test}

Hasil post test menunjukkan bahwa sebanyak 2 peserta (14\%) mendapat nilai 80 ; untuk 4 peserta (28\%) mendapat nilai 90 ; dan untuk 8 peserta (58\%) mendapatkan nilai 100 . Adapun rata-rata nilai hasil post test sebesar 94,3.

Berdasarkan hasil perhitungan dengan rata-rata sebesar 94,3 menunjukkan bahwa peserta dapat menerima dengan baik materi yang disampaikan oleh penyuluh. Hal ini terlihat dari kenaikan pengetahuan peserta setelah disampaikan materi yang dibandingkan melalui hasil pre test (nilai rata-rata 62,1).

\section{Peningkatan Nilai dari Hasil Pre Test dan Post Test}

Peningkatan dari pre test dan post test terhadap pengetahuan ibu mempunyai selisih 32,2. Peningkatan ini harapannya dapat memberikan kontribusi ilmu yang bermanfaat dalam peningkatan pengetahuan tentang stunting serta mengetahui mengolah dan menyajikan makanan yang bervariasi dan sehat dengan bahan dasar ikan kembung dan kacang kedelai untuk pencegahan stunting. Berikut tabel peningkatan hasil sebagai berikut : 
Tabel 2. Selisih Peningkatan Hasil Pre dan Post Test

\begin{tabular}{cccc}
\hline Responden & Pre & Post & Selisih \\
\hline 1 & 60 & 100 & 40 \\
\hline 2 & 60 & 90 & 30 \\
\hline 3 & 70 & 100 & 30 \\
\hline 4 & 60 & 90 & 30 \\
\hline 5 & 70 & 100 & 30 \\
\hline 6 & 60 & 90 & 30 \\
\hline 7 & 70 & 100 & 30 \\
\hline 8 & 60 & 100 & 40 \\
\hline 9 & 50 & 80 & 30 \\
\hline 10 & 70 & 100 & 30 \\
\hline 11 & 50 & 90 & 40 \\
\hline 12 & 70 & 100 & 30 \\
\hline 13 & 60 & 80 & 20 \\
\hline 14 & 60 & 100 & 40 \\
\hline Rata-rata & $\mathbf{6 2 , 1}$ & $\mathbf{9 4 , 3}$ & $\mathbf{3 2 , 2}$
\end{tabular}

\section{Angket Kepuasan Peserta}

Berdasarkan hasil pelatihan yang diikuti oleh 14 orang peserta, mengenai penjelasan tentang materi stunting, maka evaluasi yang kami peroleh dari umpan balik peserta adalah :
A) Materi yang Disampaikan

Dalam penyampaian materi 2 orang peserta (14\%) menyatakan cukup baik, 7 orang peserta (50\%) menyatakan baik, dan 5 orang (36\%) menyatakan sangat baik. Untuk lebih jelasnya dapat dilihat pada gambar berikut ini :

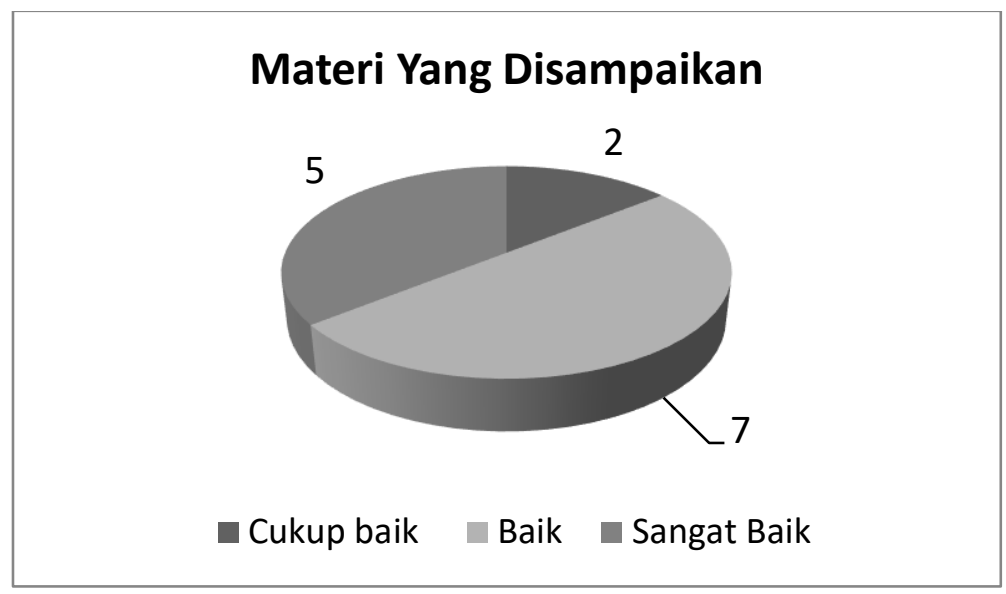

Gambar 1. Hasil Angket Kepuasan Peserta "Materi yang Disampaikan" 
B) Respon Masyarakat

Untuk respon masyarakat terdapat 5 orang $(36 \%)$ menyatakan baik ; dan 9 orang (64\%) menyatakan sangat baik. Untuk lebih jelasnya dapat dilihat sebagai berikut :

\section{Respon Masyarakat}

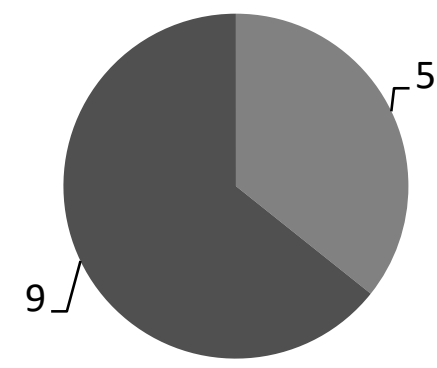

Respon Masyarakat $\square$ Baik $\square$ Sangat Baik

Gambar 2. Hasil Angket Kepuasan Peserta "Respon Masyarakat"

C) Kesesuaian Materi Dengan Kebutuhan

Untuk kesesuaian materi dengan kebutuhan terdapat 7 orang
(50\%) menyatakan baik dan 7 orang $(50 \%)$ menyatakan sangat baik. Untuk lebih jelasnya dapat dilihat sebagai berikut :

\section{Kesesuaian Materi Dengan Kebutuhan}

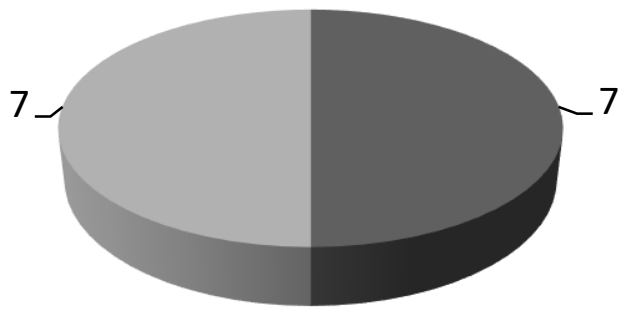

Baik $\quad$ Sangat Baik

Gambar 3. Hasil Angket Kepuasan Peserta "Kesesuaian Materi dengan Kebutuhan" 
D) Pemateri dan Teknik Penyajian

Untuk aspek pematri dan teknik penyajian terdapat 9 orang (64\%) menyatakan baik dan 5 orang $(36 \%)$ menyatakan sangat baik. Untuk lebih jelasnya dapat dilihat sebagai berikut :

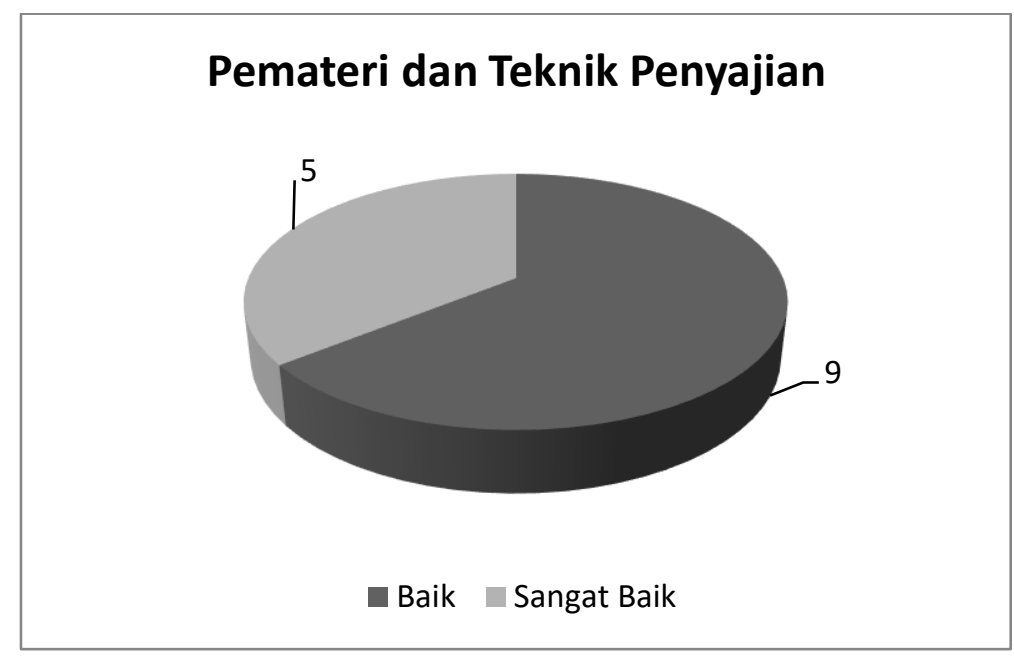

Gambar 4. Hasil Angket Kepuasan Peserta "Pemateri dan Teknik Penyajian"

E) Akses Kemudahan Link Video

Untuk aspek kemudahan link

video terdapat 8 orang $(57 \%)$

menyatakan puas dan 6 orang (43\%) menyatakan sangat puas. Untuk lebih jelasnya dapat dilihat sebagai berikut :

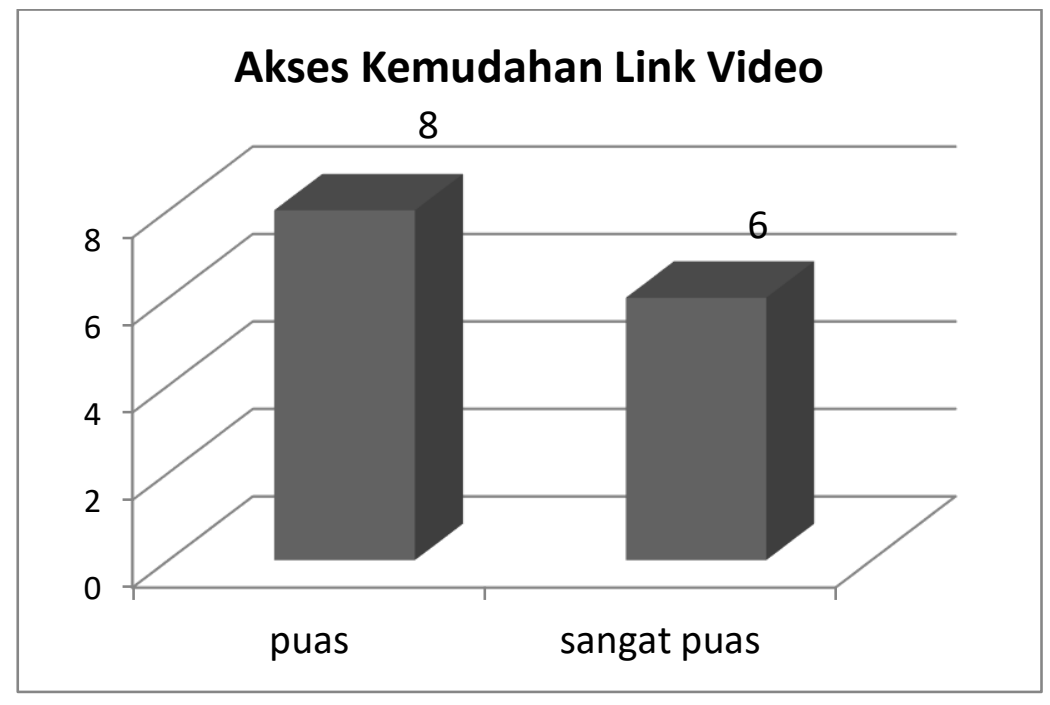

Gambar 5. Hasil Angket Kepuasan Peserta "Akses Kemudahan Link Video" 
F) Hasil Produk Pelatihan

Untuk aspek ini terdapat 8 orang (57\%) menyatakan puas ;dan 6 orang
(43\%) menyatakan sangat puas. Untuk lebih jelasnya dapat dilihat sebagai berikut :

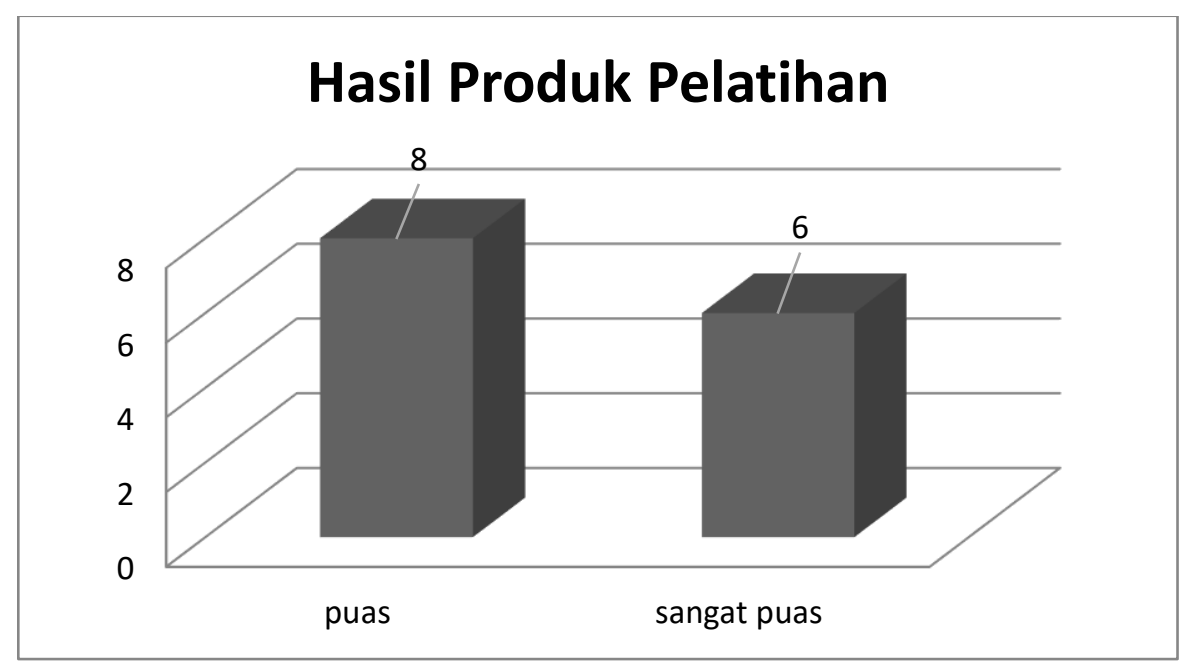

Gambar 6. Hasil Angket Kepuasan "Hasil Produk Pelatihan"

G) Kepuasan Kegiatan

Untuk aspek kepuasan kegiatan terdapat 7 orang $(50 \%)$ menyatakan puas dan 7 orang $(50 \%)$ menyatakan sangat puas. Untuk lebih jelasnya dapat dilihat sebagai berikut :

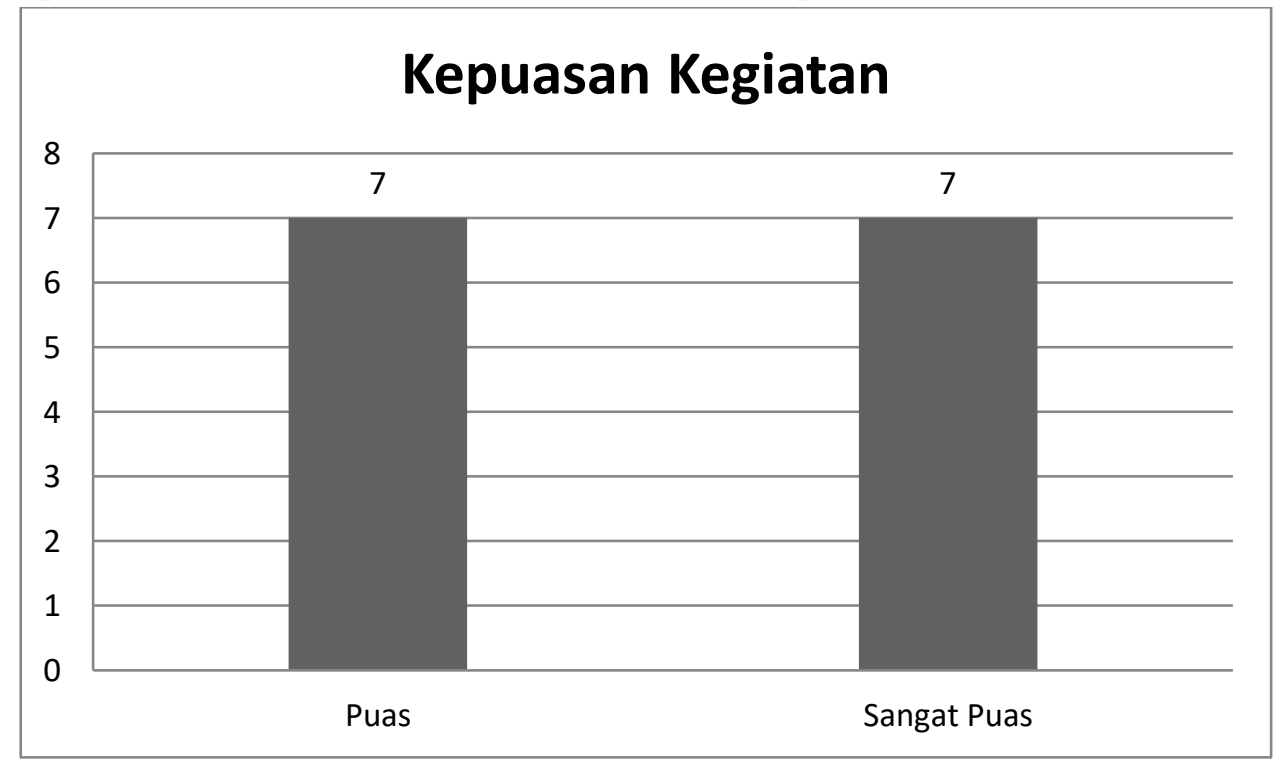

Gambar 7. Hasil Angket Kepuasan Kegiatan

Keseluruhan aspek dalam maupun pelatihan. Adapun jenis penyebaran angket terkait dengan kegiatan-kegiatan tersebut adalah $6 \%$ kepuasan pelanggan, para peserta ingin mengadakan kegiatan pembuatan menyatakan 14 orang (100\%) ingin minuman tradisional ; 13\% ingin diadakan kembali kegiatan penyuluhan mengadakan pelatihan aneka olahan kue. 


\section{PEMBAHASAN}

Berdasarkan hasil yang telah diperoleh dari kegiatan pengabdian pada masyarakat ini, diperoleh bahwa adanya peningkatan hasil pre test dan post test sebesar 32,2 tentang edukasi gizi yang diberikan guna pencegahan stunting. Hal ini didukung hasil dari kegiatan pengabdian dari pelaksana lainnya bahwa dengan adanya perilaku positif masyarakat tentang pencegahan stunting dapat timbul karena adanya kesesuaian reaksi atau respon terhadap stimulus yaitu pengetahuan tentang pencegahan stunting. Pengetahuan merupakan salah satu faktor predisposisi yang mendasari perilaku seseorang untuk berperilaku positif. Pengetahuan yang baik dapat meningkatkan perilaku masyarakat untuk melakukan pencegahan stunting secara dini (Hamzah, 2020). Hasil pengabdian masyarakat ini sejalan dengan hasil pengabdian masyarakat lainnya bahwa pada masyarakat Kecamatan Jatinagor Kabupaten Sumedang yang menyatakan bahwa gerakan pencegahan stunting melalui pelatihan meningkatkan pengetahuan kader posyandu dan melalui event HKN dapat meningkatkan pemberdayaan masyarakat dalam melakukan pencegahan stunting (Astuti, 2018).

\section{PENUTUP}

Berdasarkan hasil pelaksanaan program pengabdian kepada masyarakat, berikut beberapa kesimpulannya yaitu : Untuk aspek pengetahuan, terjadinya peningkatan dengan selisih 32,2 yang diperoleh dari hasil pre test dan post test
; Peserta antusias melaksanakan kegiatan PKM dan menginginkan diadakannya kembali kegiatan pelatihan dan penyuluhan yang lainnya. Melalui kegiatan ini, diharapkan dapat membantu upaya yang dilakukan pemerintah sehingga angka stunting akan terus menurun dari waktu ke waktu, agar segala rancangan yang telah dibuat pemerintah menghasilkan hasil yang baik. Dengan menurunnya angka prevalensi stunting artinya masyarakat dan pemerintah berhasil melakukan intervensi yang telah dilaksanakan bersama. Dampak dari kegiatan pengabdian ini adalah meningkatnya pengetahuan masyarakat tentang pencegahan stunting sebagai bentuk pencegahan dini melalui remaja puteri, ibu hamil dan ibu menyusui.

\section{DAFTAR PUSTAKA}

(UNICEF), U. N. C. F. (2017). Prevalensi Stunting Balita Indonesia Tertinggi Kedua di ASEAN.

Https://Databoks.Katadata.Co.Id/ Datapublish/2018/11/22/Prevalen si-Stunting-Balita-Indonesia-

Tertinggi-Kedua-Di-Asean\#, 2017.

https://databoks.katadata.co.id/dat apublish/2018/11/22/prevalensistunting-balita-indonesiatertinggi-kedua-di-asean

Astuti, S. (2018). Gerakan Pencegahan Stunting Melalui Pemberdayaan Masyarakat Di Kecamatan Jatinangor Kabupaten Sumedang. Jurnal Dharmakarya, 7(3), 185- 
188.

https://doi.org/10.24198/dharmak arya.v7i3.20034

Candarmaweni, \& Yayuk Sri Rahayu, A. (2020). Tantangan Pencegahan Stunting Pada Era Adaptasi Baru "New Normal" Melalui Pemberdayaan Masyarakat Di Kabupaten Pandeglang the Challenges of Preventing Stunting in Indonesia in the New Normal Era Through Community Engagement. Jurnal Kebijakan Kesehatan Indonesia : JKKI, 9(3), 136-146.

https://journal.ugm.ac.id/jkki/artic le/view/57781

Damayanti; D.S. Jastam, M.S; dan Faried, N. . (2017). Analisis Kandungan Otak-Otak Ikan Kembung (Rastrelliger brachyoma) Subtitusi buah lamun (Enhalus acoroides) Sebagai Alternatif Perbaikan Gizi di Masyarakat. Public Health Science Journal, 9(1), 19-30.

FAOSTAT. (2005). Statistical data of food balance sheet. www.fao.org

Hall, C., Bennett, C., Crookston, B., Dearden, K., Hasan, M., Linehan, M., Syafiq, A., Torres, S., \& West, J. (2018). Maternal Knowledge of Stunting in Rural Indonesia. International Journal of Child Health and Nutrition, 7(4), 139145. https://doi.org/10.6000/19294247.2018.07.04.2

Hamzah, B. (2020). Menginisiasi Perilaku Positif Masyarakat
Tentang Penyakit ISPA di Desa Muntoi Timur Kabupaten Bolaang Mongondow. Jurnal Pengabdian Masyarakat Al-Irsyad (JPMA), 2(1), 33-42.

Hardhana, B., Budiono, C. S., Kurniasih, N., Manullang, E. V, Susanti, M. I., Pangribowo, S., Harpini, A., Aprianda, R., Satriani, E., Mardina, R., Susetyoaji, E., Habibi, H. A., Sari, M., \& Sigit, B. B. (2017). Pusdatin 2017.

Kemenkes RI. (2016). InfoDATIN nfoDATIN. Scance, ISSN 2442(Hari anak Balita 8 April), 1-10.

Kemenkes RI. (2018). Buletin Stunting. Kementerian Kesehatan RI, 301(5), 1163-1178.

Kementrian Kesehatan RI. (2018). Hasil Utama Laporan Riskesdas 2018. Jakarta: Badan Penelitian Dan Pengembangan Kesehatan Departemen Kesehatan Republik Indonesia, 22. https://doi.org/1 Desember 2013

Mahmudiono, Trias and Sumarmi, Sri and Rosenkranz, R. R. (2017). Household dietary diversity and child stunting in East Java, Indonesia. Asia Pacific Journal of Clinical Nutrition, 17-325.

Meerman, J., \& Aphane, J. (2012). Impact of High Food Prices on Nutrition. In FAO's Expert Consultation on Policy Responses to High and Volatile Food Prices: Vol. FAO Nutrit (Issue November). 
https://pdfs.semanticscholar.org/c b85/80070b0dfb0b2cb251d8faf9c b7c6012b79c.pdf\%0Ahttp://www. fao.org/fileadmin/user_upload/ag n/pdf/Meerman_Aphane_ICN2_F INAL.pdf

Saputri, R. A. (2019). Upaya Pemerintah Daerah Dalam Penanggulangan Stunting Di Provinsi Kepulauan Bangka Belitung. Jdp (Jurnal Dinamika Pemerintahan), 2(2), 152-168.

https://doi.org/10.36341/jdp.v2i2. 947

Teja, M. (2019). Stunting Balita Indonesia Dan Penanggulangannya. Pusat Penelitian Badan Keahlian DPR RI, XI(22), 13-18.
Tentama, F., Delfores, H. D. L., Wicaksono, A. E., \& Fatonah, S. F. (2018). Penguatan Keluarga Sebagai Upaya Menekan Angka Stunting Dalam Program Kependudukan, Keluarga Berencana Dan Pembangunan Keluarga (Kkbpk). Jurnal Pemberdayaan: Publikasi Hasil Pengabdian Kepada Masyarakat, 2(1), 113. https://doi.org/10.12928/jp.v2i1.5 46

Tumangger, A. S. dan J. (2019). HULUHILIR PENANGGULANGAN STUNTING DI INDONESIA Rini Archda Saputri 1 Jeki Tumangger 2 Abstrak. Journal of Political Issues, 1(1), 1-9. 